\title{
The Competency Requirement of Education Profession Skill Engineers Refers To The Regional Model Competency Standards (RMCS) in The Construction Industry
}

\author{
$1^{\text {st }}$ Tri Kuncoro \\ Departement of Civil \\ Engineering, Faculty of Engineering, \\ Universitas Negeri Malang, \\ Jawa Timur, Indonesia tri.kuncoro.ft@um.ac.id \\ $2^{\text {nd }}$ Edi Santoso \\ Departement of Civil Engineering, Faculty of Engineering, \\ Universitas Negeri Malang, \\ Jawa Timur, Indonesia \\ edi.santoso.ft@um.ac.id
}

\author{
$3^{\text {rd }}$ Sudomo \\ Departement of Civil Engineering, Faculty of Engineering, \\ Universitas Negeri Malang, \\ Jawa Timur, Indonesia \\ sudomo_19@yahoo.co.id \\ $4^{\text {th }}$ Ahmad Dardiri \\ Departement of Civil Engineering, Faculty of Engineering, \\ Universitas Negeri Malang, \\ Jawa Timur, Indonesia \\ ahmad.dardiri.ft@um.ac.id
}

\begin{abstract}
Competency requirements of the Indonesian engineers expertise in the field of Civil Engineering Construction services industry, is conducted through research and development by exploring the needs of expertise competence which exists in construction services development agencies, the corporate world construction services (consultancy, supervision, and contractors), and the industry that refers to the Regional Model of Standard Competency (RMCS). The competency development refers to the RMCS, contains proficiency: (1) task skills (skills/job duties); (2) task management skills (the skills of managing a task); (3) contingency management skills (skill of anticipating possibilities); (4) job/role environment skills (the skills of managing the work environment); and (5) the ability of the transfer or adaptation in different work situations/new (transferable management skills) [3] Competency requirements for the education profession of Engineers could be developed by a college that has Faculty of engineering and professional organizations or by Union Engineers Indonesia.

The purposes of long-term development, (1) are expected to be able to answer the needs and challenges of the development in the field of engineering, information technology, and the industry in the future; (2) have the capability to compete. The competency development of engineers' expertise is, namely, building a culture of thinking, being a strong character in competing, and minded individuals in supporting the development of construction industry comprehensively. In addition, the development rises to the mentality of confidence, nature of disciplined, responsible, oriented on the quality and quality as well as participate in the development of the construction industry. The next contribution of Indonesian engineers is to be able to compete at the national, regional, and global level. The special targets: (1) the analysis needs of competency development of Engineer expertise; (2) designing and developing competency model of Engineer's profession skill.

This research employed the research and development framework [1], as follows: (1) competency analysis of expertise requirements, (2) content identification of competency skills
\end{abstract}

design, (3) devices development of competency expertise design, and (4) experts and trial validation of competency skills design; and (5) testing of competency expertise design. The results of this study showed that the development includes the understanding of utilization resources, namely; the ability of interpesonal skill, the ability to communicate, the ability to think critically of personal development, leadership, presentation skill, numeracy (numbers of skills), and digital skill.

Keywords - PII, competency, skills, and RMCS

\section{INTRODUCTION}

The profession of an engineer is becoming urgent and necessary needs of the moment. Then, to prepare competence human resources, government and other associations set up regulations in order to fulfill the needs of the job market. Regulation and standardization will be conducted within two years period to achieve the target entirely.

Indonesia desperately needs the engineer profession to face the ASEAN Economic Community (MEA). The existence of the MEA makes the competition of engineers experts becoming competitive, free and open. Thus Indonesian engineers are expected to have competency in which they can compete with the international community. The existence of the education profession is expected to answer the needs and challenges of development of the technology, industry and infrastructure. In addition, Union Engineers Indonesia (PII) has been a member of engineer organization in the world such as, World Federation of Engineering Organizations (WFEO) and ASEAN Federation of Engineering Organizations (AFEO). These organizations are expected to fulfill global needs and challenges, and also yield engineers who have the competence and can compete with other engineers from other countries in the world [10]. Engineers Indonesia Union (PII) stated that Indonesia 
shorthanded engineer expertise to deal with the ASEAN Economic Community (MEA) from 2016 until now. Indonesia still lacks a good number of eng ineers, as well as the competencies (skills)which are must-have skills for dealing with MEA and the global market. Indonesia has only 750 thousand engineers, but it's not all working in their fields or who worked as engineers are only $40 \%$. Engineers need approximately 120 thousand in the next five years (2015-2019) to support infrastructure development in the

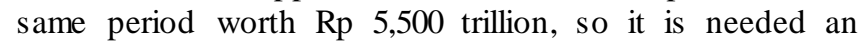
additional 65,000 new engineers per year (PII, 2015).

The needs of standard competence of Indonesian engineers in civil engineering construction services are conducted through research and development by exploring the competency needs of engineers expertise which is needed in construction services development agencies (LPJK), a business construction services (consultancy, supervision, and contractors), and the relevant industry (Kemristek higher education, 2015). The competency can be distinguished into two types: specific, i.e. it is important to perform specific or functional, technical and general competence, including intelligence concepts, information processing design, key competence, and meta competence. General competencies include the ability to prioritize, to adapt to new things, put forward ideas and new solutions, work productively with others [8].

The professional education focuses on the emphasizing of engineers expertise who have the ability, competency and performance standards. On the education of the profession required a final paper, final project, practice report, which is written based on a problem-solving or handling practically (problem based). Research on the educational program profession emphasizes the application of the theory, rather than on research and development of the theory.

The existence of professionalism proficiency in the construction is needed, where the profession in education requires a continuous process of practice and observation directly. It is not solely to be owned and known, but at the same time as the basis for an initial foothold for education learning and teaching. The engineer profession education (PPI) is a place for bachelor in engineering to apply their knowledge to get the professionalism in the field of engineering.

The development of engineer profession of Education Program i.e., refers to cultural values, mental attitude, a strong character in competing, and mentality that supports the development of construction industry comprehensively. Besides, it raises mentality of confidence, nature of disciplined, responsible, and oriented on the quality and quality as well as participating in the development. It is expected that Indonesian engineers are able to compete nationally, regionally, and globally, competitively and able to compete in the face of MEA.

Competency requirements of the Indonesian engineers expertise in the field of Civil Engineering Construction services industry, is conducted through research and development by exploring the needs of expertise competence which exists in construction services development agencies, the corporate world construction services (consultancy, supervision, and contractors), and the industry that refers to the Regional Model of Standard Competency (RMCS). The competency development refers to the RMCS, contains proficiency: (1) task skills (skills/job duties); (2) task management skills (the skills of managing a task); (3) contingency management skills (skill of anticipating possibilities); (4) job/role environment skills (the skills of managing the work environment); and (5) the ability of the transfer or adaptation in different work situations/new (transferable management skills) (ILO, 2006). Competency requirements for the education profession of Engineers could be developed by a college that has Faculty of engineering and professional organizations or by Union Engineers Indonesia.

The purposes of long-term development, (1) are expected to be able to answer the needs and challenges of the development in the field of engineering, information technology, and the industry in the future; (2) have the capability to compete with the Asean economic community (MEA). The competency development of engineers' expertise is, namely, building a culture of thinking, being a strong character in competing, and minded individuals in supporting the development of construction industry comprehensively. In addition, the development rises to the mentality of confidence, nature of disciplined, responsible, oriented on the quality and quality as well as participate in the development of the construction industry. The next contribution of Indonesian engineers is to be able to compete at the national, regional, and global level to the face of MEA.

The development of educational profession materials refers to Regional Model of Standard Competency (RMCS) and the Bakuan competence of engineers profession (BKIP) which becomes a benchmark for the assessment of qualifications, IP classification in every area of expertise, specialization and industrial sectors/services of engineering following the newest development of science and technology, the industry meet the demands of national development and excellent at the international level, in addition, BKIP package become a reference for human resources developers of professional engineers for all stakeholders, such as the educational academic, government and industry/services.

Engineers Indonesia Union (PII), started by a Service Centre 1994-1999, hosts what is referred to as the Program Engineer professionals. In this program, it will be introduced into the community: a designation (title), a new profession, namely engineers and professionalism certificates, namely professional engineer. The profession of an engineer is becoming urgent and necessary needs of the moment. Then, to prepare competence human resources, coruler of the association prepares regulation in order to answer the needs of the job market. Regulation and standardization will be done within a two years period to achieve the target entirely.

\section{METHOD}

In this present study, research and development were conducted in the service construction, profession association, and construction services development agencies located in East Java, Central Java, West Java and Jakarta. The selection of the industry is a representation factor from construction services located in Indonesia, and Asia Pacific. From the sample areas, the researcher takes a major industry, and medium industry which moves in the 
field of services construction (consultants and contractors). The researcher selected five major industries, and five medium industries, which is engaged in the field of services construction (consultants and contractors). Besides, the researcher chose five professional associations, and five construction services development agencies.

The research and development instruments employed: (1) the observation sheets, (2) question form/questionnaire, and (3) interview. Instruments and interviews are conducted to collect data from instructors expert, profession expert association, and practitioners of construction services industries.

The competence development of educational expertise of engineers the profession in the field of services construction, it intended to meet the needs of : (1) the engineer profession education: (a) expertise program development, (b) reference in training event, \& profession education assessment; and (2) resources management of performance services construction industries.

\section{RESULTS AND DISCUSSIONS}

The results of this study showed that: (1) an understanding of safety, security, and occupational health and the environment $(68,20 \%)$; (2) the ethics code and profession (63.30\%); (3) planning and designing practical mastery (67.40); (4) understanding resource utilization (7. 2, $40 \%$ ); (5) a thought to do a comprehensive evaluation $(40,60 \%)$; (6) a multidisciplinary approach to problem solving (45.80\%); (7) engineer profession behavior $(48.30 \%)$; and the act of decision making $(69.70 \%)$.

\section{A. Understanding Resource Utilization}

Services construction industries include some resources, and the most dynamic resource that is human resources. The competence of human resources is expected to improve performance system to be better. In improving the construction industry is needed an improvement capability, it is not just individual but also team capabilities, and also corporate capabilities. The needs of the construction industry capabilities need to be continuously developed in answering the implementation of technological developments, materials and industrial equipment. Therefore, the design of which is clearly much needed long term in order to ensure that the corporation's capabilities can be fulfilled and answer the needs of the industrial market. Capabilities can be expressed as individual behavior can be demonstrated, or behaviors that indicate the minimum performance standards. Hoffamnn (2007) explains there are three scope capabilities (1) the performance of the observation (2) quality standards or results that can be filled with a person, (3) attribute of a person that can be recorded (knowledge or skill or ability) that determines its performance.

Capabilities (individual, team, and organization) of badly needed, organizations or corporations not only to meet the needs of the owner, but will also increase the value of the construction industry in answering the challenges of the development of technology implementation, material and equipment that is more innovative. Furthermore, the construction industry capability that is able to answer the challenges of the market needs of the future. Human resource is an important factor in the development of the construction services sector. The creation of human resources and quality of work are ready to meet the challenges of the market of construction services is a program of short and long term needs to be prepared early on. Design of human resources as a systematic process of reviewing, the review, and ensure that the condition of human resources that exist within a certain period, the quality, the right skills, will number: available at the time they are needed [5].

Kaplan (2000), human resources planning as a management process; in determining the movement of human resources in the Organization and of its position when employment towards the desired position in the future. General Competencies include a series of constructions, such as intelligence, information processing, competency models are the key, and the competence of meta. Group competence is characterized by the ability to be applied in the context of Indonesia and different content. Moreover, this type of competence supports the process of implementation the specific competencies of the existing as well as new development in the situation and the new work environment. Some scientists have proposed the integrated conceptual model unite both specifically and general competence, to meet the needs of the cognitive, motivational and social [2].

In the planning of human resources labor is the process of planning, developing, and implementation control that guarantees the conformity of the construction services company had a number of employees, placement officer, and a very precise time economically beneficial. Human resources planning is a process/system for assigning work to power needs a certain period either in quality or quantity with certain methods. Siagian (1994) States, HR planning is a certain step taken by management personnel to provide proper power to occupy various positions, the position and the right job, at the right time in the the framework of the achievement of the objectives that have been and will be set.

[9] human resource planning is expressed as a way to try to resolve the labor needs for a certain period either in quality or quantity in ways. Planning is intended so that the company can avoid the scarcity of human resources in times of need as well as the advantages of human resources at a time when less is needed.

The needs of the construction industry in recruiting employees/workforce, that is, who has the Soft skills that go beyond skill qualifications and experience. Soft skill, which means it can be transferred to different jobs and different employment sectors. For entrepreneurs, getting the right people means to identify individuals with the right skills and qualities to fulfil its role and contribute to the success of the construction industry. Workers who have qualifications and appropriate skills as well as ' a set of soft skills are good, so needed to be able to manage the implementation of a systematic work.

Construction workers are an important element in increasing the productivity of the construction industry in the field of construction services. The worker is a major factor in increasing the productivity of the construction industry, therefore the productivity of workers (labor productivity) need to be always maintained, developed and improved. Workers are the human resources that give you 
the greatest influence on the enhancement, development, and capacity on the productivity of the construction industry. In addition, factors that can improve the performance experts (Engineers), namely by training competency in accordance with the functions and duties anyway.

In improving the understanding of the workers, about the proper building construction workers (labor) will need to be trained in the appropriate competence functions and its work. In addition to being able to assist workers in understanding and improving the knowledge, skills, behaviour in understanding the technology implementation of the construction and development of the technology of building materials. In addition to understanding, also brings the benefits of increasing the competence of the construction workers would have knowledge of the culture of working in team work and recognize new competitors who brought a new culture technology of implementation of construction and building materials recently. It helps the construction workers increase their skills for working with new technologies, understand how to work for the team effectively to produce quality construction services [4].

Employability Skills?, i.e. job skills needed to get, inovation and execute the job well. Soft skills include: interpesonal ability, the ability to communicate critical thinking ability, personal development, leadership, presentation skills, numeracy (counting skills), and digital skills https://www.skillsyouneed.com)/general/employabilityskills.html

Employability Skills are the skills and attitudes that enable employees to get along with a colleague, make decisions, solve problems, urgent to develop respect and can eventually raise the company. Generic Competences such as conceptual or ability to learn communication skills and teamwork more slasher sub-genre wereg for success [7].

Interpersonal skills are very important in completing the work and is the only important factor for many recruiters. Interpersonal skills are skills that we use to interact with a colleague. Good interpersonal skills allow you to effectively participate as a team member, meet the expectations of customers and clients, negotiate, make decisions, manage your time efficiently, responsibly, and works in effectively with other workers. [6] found that the competence of the leader of the related projects, job satisfaction and job satisfaction play a role of mediation in the relationship between the competence of the leadership and performance of similar projects, including understanding of individual competency interpersonal, commitment, critical thinking, persuasive and collect information has proved to contribute to effective performance [11].
Good interpersonal skills are often seen as the bas is for a working relationship and social good, and also to develop many other areas of expertise. Good interpersonal skills, ease in developing other important life skills. Therefore, the need to spend time developing good interpersonal skills. Interpersonal skills (soft skills) is used every day and in every area of our lives. Good interpersonal skills allow us to empathize and build rapport with colleagues and clients, which leads to a better working environment. Interpersonal skills include: negotiation, decision making, problem solving, relationship building .

\section{CONCLUSIONS}

The expertise competency of engineer profession employed in competing in global competition needs to be done in order to develope competence in the fields of expertise, with soft skill development including: interpesonal skill, communication skill, critical thinking skill of self-development, leadership, presentation skills, numeracy (counting skill), and digital skill.

\section{REFERENCES}

[1] Borg, w. r., and Gall, m. d. 1989. Educational Research: An Introduction (5th ed.). New York: Longman.

[2]. Boyatzis, R.E., 1982. The Competent Manager: A model for Effective Performance, John Wiley \& Sons, New York.

[3] ILO (International Labour Organization). 2006. Regional Skills and Employability Programme (SKILLS-AP). Guidelines for Development of Regional Model Competency Standards (RMCS). Bangkok: International Labour Organization.

[4] Noe, Raymond a., John r. Hollenbeck, Barry Gerhart, and Patrick m. Wright. 2006. Human Resource Management: Gaining a Competitive Advantage. 5th ed. Boston: McGraw-Hill/Irwin, 2006.

[5] Soeparto, G., Bambang Trigunarsyah. 2005. Indonesia's construction industry: the future and the challenge. Commemoration of 25 years of education at the University of Indonesia MK.

[6] Stumpf, S.A. 2010. Competency assessments of u.s. stakeholders predict ors of career success, Career Development International, vol. 15 Iss: 5, pp. 459-478

[7] Thompson m., 2000. Gender, Orientation, and Leadership Effectiveness: Testing the Theoretical Models of Bolman and Deal \& Quinn, Sex Roles, 42,11/12,969-992.

[8] Trivellasa,Panagiotis *,Zoe Akrivoulib, Evdokia Tsiforab, Paraskevi Tsoutsa. 2015. The impact of knowledge sharing culture on job satisfaction in accounting firms. The mediating effect of general competencies. Procedia Economics and Finance 19 (2015) 238 $\underline{247 .}$

[9] Usmara, a., 2002. The new paradigm of human resource management, Yogyakarta: Amara books

[10] Wibowo, Yanfauni Ade Pradena. 2016. get to know the profession of Engineer Education Program. Wednesday (13/4) of the Ministry of research, higher education and T echnology held Socialization Of The Opening Of The Profession Of Engineer https://www.selasar.com/sainstek/mengenal-program-pendidikanprofesi-insinyur, retrieved Tuesday, April 26, 2016.

[11] Zhang, z., w. Luk, Arthur d., \& Wong, T (2001) Nursing competencies: personal characteristics contributing to effective nursing performance. Journal of Advanced Nursing, 33 (4): 467-74. 